\title{
DINAMIKA PERILAKU AGRESIF ANAK YANG BERMAIN GAME PADA ANAK KELOMPOK B4 DI TK ABA WONOCATUR BANGUNTAPAN BANTUL
}

\author{
Delfiana Anggraini Permatasari, Dr. Sugito, M.A, Arumi Savitri F, M.Psi \\ Pendidikan Anak Usia Dini Universitas Negeri Yogyakarta \\ email:ana_delfi@yahoo.co.id, sugito@uny.ac.id, arumi@uny.ac.id
}

\begin{abstract}
Abstrak
Penelitian ini bertujuan untuk mengetahui dinamika perilaku agresif anak yang bermain game pada anak Kelompok B4 di TK ABA Wonocatur Banguntapan Bantul bedasarkan teori $\mathrm{ABC}$ (Antecedent, Behavior, dan Consequence). Alasan mengambil penelitian ini karena diketahui anak berperilaku agresif disebabkan oleh beberapa faktor yang salah satunya karena faktor bermain game. Hal ini terlihat saat anak-anak tersebut menampilkan perilaku agresifnya seolah-olah sedang menirukan perilaku yang ada di game. Penelitian ini merupakan jenis penelitian kualitatif dengan pendekatan studi kasus. Penelitian yang dilakukan melibatkan subjek sebanyak 7 orang yang terdiri dari tiga orang orangtua anak, tiga anak yang berperilaku agresif, dan satu guru kelas. Pengumpulan data dilakukan dengan teknik wawancara dan teknik observasi. Hasil data yang telah diperoleh dianalisis menggunakan model analisis interaktif dengan mengunakan formula $\mathrm{ABC}$ (Antecedent, Behavior, dan Consequence). Berdasarkan penelitian yang telah dilakukan didapatkan hasil bahwa anak lebih sering berperilaku agresif dalam bentuk fisik dikarenakan terdapat anteseden yang mana diketahui anak tersebut telah memiliki kebiasaan bermain fighting game yang di dalamnya terdapat adegan berkelahi seperti memukul dan menendang. Ketika perilaku sudah terbentuk karena dipengaruhi anteseden maka akan muncul konsekuensi yang harus diterima oleh anak. Penyebab perilaku agresif anak selain bermain game juga dipengaruhi faktor peran orangtua dan teman sebaya.
\end{abstract}

Kata kunci: perilaku agresif, game, peran orang tua

\section{THEDYNAMICSOFCHILDRENAGGRESSIVEBEHAVIORINPLAYINGGAME AT GROUPB4OFTKABAWONOCATURBANGUNTAPANBANTUL}

\begin{abstract}
This study aimed to reveal the dynamics of children aggressive behavior who playing game at group B4 in TK ABA Wonocatur, Banguntapan Bantul based on ABC (Antecedent, Behavior and Consequence) theory. Known children who behave aggressively because by several factors, that one of the factors were playing game. These factors could be seen when the childrens show their aggressive behavior by imitating the action in the game. This study could be categorized as qualitative research with case study approach. The research subjects involved 7 persons consisting of three parents, three aggressive children and a teacher. Data collection technique was using interview and observation. The data analysis technique was using interactive analysis model with ABC (Antecedent, Behavior, and Consequence) formula. The research result showed that children behave aggressively more on physical form because there was antecedent from their habit of playing fighting game which scenes like hitting and kijing. When a behavior was formed because of the antecedent influence, the consequences appeared and must be accepted by the children. Other causes of children aggressive behavior were also influenced by the factors of parents and peers role.
\end{abstract}

Keywords: aggresive, behavior, game, parents' role

PENDAHULUAN

Anak usia dini merupakan anak yang berusia 0-6 tahun. Pada setiap masa

yang akan dilewati anak akan menunjukkan 
perkembangannya masing-masing. Salah satu perkembangan yang harus dicapai oleh anak adalah perkembangan emosi. Emosi dapat diterjemahkan sebagai perasaan dari individu yang dapat berupa perasaan positif ataupun perasaan negatif sebagai akibat dari reaksi dari suatu keadaan yang melingkupinya. Hal ini disebabkan juga akibat dari adanya interaksi diantara individu dengan individu lainnya (Wiyani, 2014: 22-23).

Seorang individu akan dilingkupi emosi positif dan emosi negatif dalam kesehariannya. Menurut Lazarus (Mashar, 2011: 31), emosi positif merupakan emosi yang memberi keuntungan. Adapun contoh emosi positif anak diantaranya kebahagiaan, rasa senang, bangga, cinta, pengharapan dan perasaan terharu atau belas kasihan. Sedangkan emosi negatif merupakan emosi yang berasal dari interaksi yang mengancam atau kondisi yang menyakitkan. Adapun emosi negatif terdiri dari marah, cemas, rasa malu, atau bersalah, kesedihan, cemburu dan jijik.

Terdapat beberapa karakteristik emosi negatif anak yang didapatkan dari hasil penelitian yang telah dilakukan oleh Izzaty (2005: 86) di Taman Kanak-kanak di Yogyakarta. Adapun hasilnya menunjukkan adanya permasalahan umum salah satunya perilaku agresif. Menurut Rahman (2013: 197), perilaku agresif adalah perilaku melukai orang lain baik secara fisik maupun psikis.

Menurut hasil penelitian yang dilakukan oleh Arriani (2014: 22) yang berjudul "Perilaku Agresif Anak Usia Dini" yang dilakukan di PAUD Mustika Ceria terhadap 5 orang siswa yang berperilaku agresif menunjukkan perilaku yang beragam. Bentuk perilaku kelima anak tersebut terdiri dari agresif fisik, agresif yang meledak, agresif lisan, dan agresif secara tak langsung. Perilaku tersebut terlihat ketika anak belajar maupun saat bermain. Setiap hari kelima anak tersebut sering memicu terjadinya kericuhan di sekolah.

Untuk mengetahui perilaku agresif secara mendalam, diperlukan analisis secara mendalam yaitu analisis fungsi.
Dalam analisis ini informasi yang relevan dikumpulkan sesuai dengan permasalahan perilaku agresif. Analisis fungsi tersebut menggunakan formula $\mathrm{ABC}$.

Adapun formula tersebut adalah Antecedent, Behavior, and Consequences. Antecedent (anteseden) merupakan peristiwa lingkungan yang membentuk tahap atau pemicu perilaku. Secara reliabel anteseden mengisyaratkan waktu untuk menjalankan sebuah perilaku yang dapat meningkatkan kecenderungan terjadinya suatu perilaku pada waktu dan tempat yang tepat. Anteseden yang terjadi secara alamiah (naturally occuring antesedents) secara otomatis dipicu oleh peristiwa yang berkaitan dengan lingkungan. Dalam operant conditioning anteseden dapat memberikan petunjuk bahwa sebuah perilaku dapat menimbulkan konsekuensi yang positif atau negatif. Menurut Skinner (Fajri, 2014: 9) untuk menghasilkan perubahan perilaku pada diri individu selain memperhatikan konsekuen juga digunakan anteseden-anteseden. Perilaku manusia seperti sebuah sandwich atau serangkaian antecedents-behavior-consequens (A-B-C). Ada dua cara untuk mengontrol anteseden agar menghasilkan perilaku baru atau perubahan perilaku, yaitu dengan cueing dan prompting. Menurut Kwick (Kholid, 2012: 60-61), Behavior (perilaku) merupakan tindakan-tindakan atau perbuatan organisme yang dapat diamati bahkan dipelajari. Pada hakikatnya perilaku manusia adalah tindakan atau aktivitas dari manusia itu sendiri yang mempunyai bentangan yang luas. Contoh perilaku manusia yaitu berjalan, berbicara, menangis, tertawa, bekerja, kuliah, menulis, membaca, dan sebagainya. Nelson dan Hayes (Priyoto, 2014: 129) memaparkan bahwa ciri-ciri suatu perilaku membawa implikasi penting bagi penyusunan strategi komunikasi.

\section{Consequences}

(konsekuensi)

merupakan peristiwa lingkungan yang mengikuti sebuah perilaku. Konsekuensi dapat menguatkan, melemahkan atau menghentikan suatu perilaku. Pada umumnya orang cenderung mengulangi perilaku-perilaku yang membawa hasil-hasil positif dan menghindari perilaku-perilaku 
yang memberikan hasil-hasil negatif.

Menurut Geller (Erlianti \& Dwiyanti, 2014: 95), penggunaan model perilaku $\mathrm{ABC}$ merupakan cara yang efektif untuk memahami sebab-sebab perilaku agresif bisa terjadi. Selain itu juga dapat mengetahui konsekuensi yang muncul akibat perilaku agresif. Teori dalam model perilaku $\mathrm{ABC}$ ini sesuai dengan The lawfullness of behavior dalam ilmu perilaku yang disampaikan oleh As'ad (Erlianti \& Dwiyanti, 2014: 95). Adapun tingkah laku manusia timbul karena adanya stimulus. Tidak ada tingkah laku manusia yang terjadi tanpa adanya stimulus. Stimulus atau anteseden merupakan sebab terjadinya perilaku dan semakin besar anteseden yang ada maka semakin besar kemampuan manusia untuk meningkatkan tingkah lakunya.

Salah satu faktor yang menjadi anteseden perilaku agresif adalah faktor bermain game. Henry (2010: 1) berpendapat bahwa game merupakan salah satu media yang sedang berkembang pesat selama 20 tahun belakangan ini. Sudah tak dapat dipungkiri lagi game sudah menjadi salah satu budaya dan ada dalam kehidupan manusia. Game tidak hanya digemari oleh kaum remaja, melainkan anak umur mulai 3 tahun sudah ada yang mengenal berbagai jenis perangkat game. Dengan bermain game anak akan mengalami kecanduan. Kecanduan game membuat anak menjadi kasar, suka mencaci, dan sampai kehilangan pengendalian diri. Setiap anak pasti memiliki kebutuhan akan bermain. Di antara sekian banyak permainan yang ada di pasaran, terdapat beberapa permainan yang perlu diwaspadai apabila anak terlalu sering memainkan game. Ketika anak bermain game, permainan yang menggunakan stik dan layar televisi, adrenalinnya akan memuncak, marah yang disertai berteriak, membentak dan mencaci (Musbikin, 2009: 139-140).

Anak meniru perilaku dalam game. Menurut teori modelling yang dikemukakan oleh Bandura (Singgih, 2006: 175), tayangan pada TV, film video (VCD/DVD), game dapat menjadi perilaku model bahan cognitive form anak. Model perilaku cognitive form menjadi bahan referensi di alam bawah sadar anak. Perilaku model seperti agresif, tidak menghargai orang lain, mudah menembak/membunuh orang lain dapat menjadi model yang akan diendapkan anak dalam cognitive form-nya yang mana sewaktu-waktu akan muncul dalam bentuk perilaku. Anak dapat mudah menyaksikan berbagai perilaku model dalam tayangan televisi dan game. Anak mengamati model-model yang dilihat dalam hal berbagai perilaku, cara bertindak, cara memperlakukan orang lain. Perilaku model tersebut akan mudah diserap dan disimpan pada isi bawah sadarnya serta dapat menjadi pengaruh ketika anak berperilaku.

Seorang pemain game atau biasa disebut dengan gamer memainkan game secara berulang dan terus-menerus dapat meningkatkan perilaku agresif. Anderson, Gentle, dan Buckley (Vanri \& Hasbiyalloh, 2011: 3) menuturkan bahwa perilaku agresif yang muncul dapat bersifat verbal, fisik atau kekerasan, dan relasi. Agresif verbal adalah agresif berbentuk perkataan yang menyakitkan secara verbal seperti caciancacian atau kata-kata kotor akibat isi yang ada di dalam permainan. Kemudian agresif fisik atau kekerasan adalah jenis perilaku agresif yang paling banyak terjadi setelah pemain bermain game. Sedangkan agresif secara relasi adalah kerusakan hubungan atau relasi sosial berupa perasaan ditolak dari lingkungan, persahabatan, atau pelibatan pada kelompok tertentu.

Anak yang bermain game menjadi berperilaku agresif karena anak memainkan game yang terdapat unsur kekerasan. Dalam teori GAM (General Aggression Model) menyatakan bahwa game yang berbau kekerasan memiliki efek jangka pendek dan jangka panjang. Dalam efek jangka pendek, game merupakan variabel situasional yang mana menimbulkan adanya peningkatan dalam kognisi, pengaruh, dan menggerakkan semuanya agresif. Efek jangka panjangnya hanya menjadi hipotesis, dikarenakan berbagai penelitian yang telah dilakukan tidak cukup untuk menguji efeknya. Diperkuat lagi oleh Anderson dan Bushman (Sokolova, 2014: 119) menghipotesiskan bahwa video game 
berbau kekerasan dapat menimbulkan perilaku agresif. Contohnya pada game "Super Mario Bros". Game ini merupakan game fiksi yang diperankan oleh karakter kartun. Karakter utamanya selalu menghancurkan gedung dan berusaha melompat di atas kepala. Dari sisi inilah sudah tampak sekali bahwa game seri "Super Mario Bros" berbau kekerasan.

Contoh lain dapat dilihat di game "Mortal Kombat" yang menampilkan fitur dengan grafis dan kontrol yang realistis. Selain itu juga darah dan pelukaan yang ekstrem. Dalam permainan ini, pemain memerangi lawan seperti manusia dalam usaha untuk melumpuhkannya. Pertandingan dianggap selesai jika terjadi fatalitas/kematian, sebuah pergerakan yang membunuh lawan pemain dalam suatu mode yang sangat grafis. Fatalitas umum itu juga termasuk membakar lawan hiduphidup, memenggal kepalanya, dan bahkan menghancurkan tulang belakangnya dengan menggunakan tengkorak. Permainan ini sangat mempengaruhi standar permainan berbau kekerasan pada zaman sekarang (Sokolova, 2014: 119120).

Hasil penelitian yang dilakukan oleh Craig et.al. (2001: 358) tentang "Effects Of Violent Video Games On Aggressive Behavior, Aggressive Cognition, Aggressive Affect, Physiological Arousal, And Prosocial Behavior: A Meta-Analytic Review Of The Scientific Literature" di Amerika yang berjumlah 4.262 peserta dan sekitar setengah dari peserta $(46 \%)$ berada di bawah 18 tahun bahwa konten kekerasan pada video game menimbulkan ancaman kesehatan dan efek merugikan bagi masyarakat pada umumnya dan anak-anak pada khususnya. Sebagian besar penelitian ini adalah eksperimental, sehingga menunjukkan hubungan sebab akibat antara konten kekerasan pada video game dan kognisi agresif. Oleh sebab itu, video game yang berisi kekerasan dapat meningkatkan perilaku agresif pada anak yang memainkannya dalam jangka pendek. Perilaku agresif dapat memunculkan dampak atau konsekuensi yang beragam. Menurut Nors (2011, http://m.kompasiana.com/icha nors/perilak u-agresif-penyebab-dan penanganannya), salah satu dampak dari perilaku agresif yaitu anak tidak memiliki kemampuan bergaul dengan teman-temannya. Hal yang demikian membuat anak menjadi semakin tidak diterima oleh lingkungannya sehingga perilaku agresif semakin menjadi-jadi. Ketika perilaku tersebut semakin menjadijadi dapat membahayakan anak itu sendiri dan orang lain. Pendapat tersebut dipaparkan oleh Saefi (2010, http://belajarpsikologi.com/pengertianperilaku-agresif/) bahwa perilaku agresif sering sekali menimbulkan masalah baik di sekolah maupun di rumah.

Mengingat dari berbagai fenomena perilaku agresif yang terjadi pada anak usia dini perlu dilakukan penelitian mengenai dinamika perilaku agresif anak yang bermain game di Kelompok B4 TK ABA Wonocatur. Di Kelompok B4 TK ABA Wonocatur dalam satu kelas yang berisi 20 anak terdapat 3 anak yang perilakunya sangat menonjol dan sering menyakiti temannya. Bentuk perilaku agresif anak tersebut seperti menjewer, memukul, menampar, menendang, mendorong, menabrak, merusak mainan, menginjak, menyundul, menyikut, menjambak, menyenggol, menarik baju, menindih, dan memelintir jari.

Ketiga anak yang berperilaku agresif tersebut disebabkan oleh beberapa faktor yang salah satunya karena faktor bermain game. Hal ini terlihat saat anak-anak tersebut menampilkan perilaku agresifnya seolaholah sedang menirukan perilaku yang ada di game.

Anak yang berperilaku agresif tersebut sering memainkan game yang berisi konten kekerasan. Saat menampilkan perilaku agresif, anak seolah-olah seperti dalam game kekerasan yang biasa dimainkan

Berdasarkan uraian latar belakang dan identifikasi masalah, maka penelitian ini perlu adanya batasan masalah supaya hasil penelitian mendapat hasil yang fokus. Oleh karena itu peneliti memfokuskan masalah pada dinamika perilaku agresif anak yang 
bermain game pada Kelompok B4 TK ABA Wonocatur, Banguntapan, Bantul.

Adapun tujuan utama dilakukannya penelitian adalah untuk mengetahui dinamika perilaku agresif anak yang bermain game di Kelompok B4 TK ABA Wonocatur, Banguntapan, Bantul.

Dari manfaat teoritisnya, penelitian ini diharapkan dapat memberikan informasi mengenai dinamika perilaku agresif pada anak yang bermain game di Kelompok B4 TK ABA Wonocatur. Selanjutnya penelitian ini dapat dimanfaatkan untuk penelitian lebih lanjut dan masalah lain yang berkaitan dengan perilaku agresif anak yang bermain game sebagai salah satu bahan yang memperkaya penelitian khususnya bidang pendidikan anak usia dini.

Sedangkan bagi orangtua, penelitian ini dapat dijadikan acuan dalam tindakan kontrol pada anak yang bermain game pada perangkat handphone dan pendampingan khusus agar anak tidak salah bermain game yang berisi kekerasan. Bagi guru, hasil penelitian ini dapat dijadikan pertimbangan dalam mengantisipasi dan menangani anak yang berperilaku agresif yang mungkin muncul di sekolah akibat bermain game.

\section{METODE PENELITIAN}

Penelitian ini merupakan jenis penelitian kualitatif dengan pendekatan studi kasus. Penelitian dilakukan di sekolah dan tempat tinggal anak yang bersekolah di TK ABA Wonocatur Banguntapan Bantul. Tempat tersebut dipilih sebagai tempat penelitian berdasarkan beberapa pertimbangan. Pertimbangan tersebut adalah karena anak melakukan kegiatan bermain game banyak dilakukan di rumah. Penelitian dilakukan mulai tanggal $1 \mathrm{Mei}$ 2017 sampai pada tanggal 15 Juni 2017.

Objek penelitian yaitu dinamika perilaku agresif anak yang bermain game yang ada di Kelompok B4 di TK ABA Wonocatur Banguntapan Bantul. Agar tercipta kebaikan bersama dalam penelitian sesuai dengan etika penelitian, maka nama anak diberikan inisial. Berikut merupakan tabel inisial, jenis kelamin dan usia anak yang akan menjadi objek penelitian.

Tabel 1. Daftar Inisial Anak Berperilaku Agresif di TK ABA Wonocatur Banguntapan, Bantul

\begin{tabular}{|r|c|c|c|}
\hline No. & Inisial & Jenis Kelamin & Usia \\
\hline $\mathbf{1}$ & SA & Laki-laki & 7 tahun \\
\hline $\mathbf{2}$ & LI & Laki-laki & 6 tahun \\
\hline $\mathbf{3}$ & DA & Laki-laki & 6 tahun \\
\hline
\end{tabular}

Pengambilan data penelitian ini menggunakan teknik pengumpulan data wawancara dan observasi. Observasi dilakukan ketika anak berada di sekolah dan di rumah. Penelitian dilakukan mulai tanggal 1 Mei 2017 hingga 15 Juni 2017. Wawancara dilakukan pada guru TK ABA Wonocatur yang terlibat dalam kegiatan anak saat berada di sekolah. Selain kepada guru, wawancara juga akan dilakukan kepada orangtua.

Keabsahan data dalam penelitian yang dilakukan oleh peneliti menggunakan teknik triangulasi sumber. Diperlukan analisis data secara mendalam yaitu menggunakan analisis fungsi. Analisis fungsi ini mengunakan formula $\mathrm{ABC}$ (Antecedent, Behavior dan Consequence). Analisis data dalam penelitian kualitatif di TK ABA Wonocatur dilakukan sejak sebelum memasuki lapangan, observasi, selama penelitian di lapangan dan setelah selesai penelitian di lapangan. Adapun proses analisis data selama di lapangan menurut model Miles dan Huberman yaitu reduksi data, penyajian data dan penarikan kesimpulan.

\section{HASIL DAN PEMBAHASAN Hasil}

Berikut merupakan perilaku agresif yang ditemukan pada anak di Kelompok B4 TK ABA Wonocatur Banguntapan Bantul yang diperoleh data hasil wawancara yang berupa catatan wawancara dan hasil observasi selama 21 hari berupa catatan lapangan. Hasil observasi perilaku agresif menggunakan pola $\mathrm{ABC}$ dilakukan dengan mengamati aktivitas anak dan mencatat perilaku agresif yang muncul, pemicu terjadinya perilaku agresif (antecedents), dan akibat yang mengikuti (consequences). Perilaku agresif yang muncul diketahui dari gejala dan bentuk agresifnya. Adapun 
antasedennya dilihat dari faktor penyebab perilaku agresif. Sedangkan konsekuensinya dilihat dari akibat yang ditimbulkan dari perilaku agresif yang dilakukan anak. Berikut ini dipaparkan hasil data yang diperoleh.

\section{Gejala Perilaku Agresif}

Gejala perilaku agresif yang biasa dilakukan oleh anak muncul dalam 3 bentuk yaitu provokasi, mengganggu dan merusak benda. Provokasi yang biasa terjadi pada anak yaitu sebuah tindakan yang bersifat membangkitkan amarah teman-temannya untuk mencapai sesuatu yang diinginkan oleh anak. Dalam dunia pertemanan anak, sudah hal lumrah apabila anak tidak ingin berdekatan dengan teman yang sedang dimusuhi olehnya. Dengan begitu, anak akan mempengaruhi temanteman yang lain untuk tidak berdekatan dengan musuhnya tersebut. Faktor yang mendorong anak melakukan provokasi salah satunya disebabkan adanya rasa benci.

Mengganggu merupakan perbuatan yang ditujukan untuk menghambat kegiatan orang lain. Tindakan mengganggu biasanya dilakukan secara sengaja oleh anak. Ketiga anak sering mengganggu teman-temannya dengan keusilan tangannya. Bentuk mengganggu anak ada 7 bentuk seperti menggelitik, mengambil tutup spidol, menyenggol, menjejak, menarik celana, menjawil, dan membuka baju.

Seringkali anak merusak benda-
benda di sekelilingnya sebagai
pelampiasan kemarahannya. Benda-benda
tersebut dipukul berulangkali hingga
menjadi rusak dan ditempatkan di
sembarang tempat. Gejala perilaku agresif
yang dilakukan anak didasarkan karena
memang ketiga anak tersebut merupakan
anak yang aktif. Hal ini yang membuat
mereka selalu ingin bergerak melakukan
apa saja termasuk menjawil, menyenggol
dan lain-lain. Perilaku tersebut membuat
anak yang lain menjadi tidak nyaman dan
terganggu. Selain itu, apabila ketiganya
saling duduk bersebelahan atau dengan
sasarannya maka itulah kesempatan
mereka untuk mengganggu. Gejala agresif

yang muncul oleh ketiga anak tersebut merupakan perilaku yang bersifat negatif yang dilakukan secara sengaja.

\section{Bentuk Perilaku Agresif}

Bentuk perilaku agresif yang biasanya dilakukan pada LI yaitu berbentuk fisik dan verbal. Agresif berbentuk fisik pada umumnya dilakukan secara fisik dengan melukai atau melakukan kekerasan untuk menyakiti seseorang. Adapun contoh dari bentuk fisik yang sering dilakukan anak yaitu memukul. Sedangkan perilaku agresif verbalnya seperti mengejek dan berkata kasar.

Adapun contoh dari bentuk fisik yang sering dilakukan DA yaitu memukul dan menarik baju. Memukul adalah melakukan tindakan dengan mengenakan suatu benda yang keras dan kuat dengan kekuatan. Sedangkan bentuk verbalnya seperti mengejek, mengancam, dan memaki. Berbeda dengan bentuk fisik yang sering dilakukan SA yaitu memukul, menendang, mendorong, dan menarik tangan. Adapun bentuk verbalnya hanya memberontak.

\section{Penyebab Perilaku Agresif}

Penyebab perilaku agresif pada anak disebabkan oleh dua faktor yakni faktor internal dan faktor eksternal. Faktor internal berasal dari dalam diri anak itu sendiri. Adapun faktor internalnya adalah emosi dan kepribadian. Sedangkan faktor eksternal berasal dari luar diri anak. Faktor eksternal penyebab perilaku agresif pada anak yaitu pola asuh, lingkungan dan game. Penelitian ini berfokus pada faktor penyebab anak menjadi berperilaku agresif dikarenakan faktor game. Hal tersebut didukung oleh data di lapangan sebagai berikut.

LI dapat berperilaku agresif setelah LI bermain game yang terdapat tayangan/adegan perkelahian. Saat memainkannya LI terlihat diam dan fokus ke game tersebut. Hal inilah yang membuat LI langsung akan mengikuti adegan tersebut setelah bermain game. Adapun adegan perkelahian yang ada di dalam game tersebut seperti memukul dan menendang. LI memang mudah sekali terpengaruh oleh sesuatu hal yang dia lihat sendiri.

Selain LI, DA menunjukkan perilaku agresifnya ketika di sekolah. Saat istirahat 
tiba DA mengajak teman-temannya untuk bermain perang-perangan. Pada mulanya DA menyerang teman yang dianggap musuhnya dengan memukul terlebih dahulu seakan-akan dia sedang bermain game. Musuhnya membalas hal yang sama. Mereka saling membalas satu sama lain. DA memukul seperti menirukan adegan dalam game berkelahi dan pukulan DA menjadi keras hingga membuat sasarannya kesakitan. DA terus menyerang temannya yang seakan-akan adalah musuh yang harus dimatikan. Ketika guru telah memberi peringatan pun, DA terus menyerang hingga musuhnya/temannya merasa kelelahan.

Hal yang sama juga dilakukan oleh SA. Saat istirahat tiba, SA mengajak LE untuk bermain peran menjadi monster. Mula-mula SA menyerang LE dengan mendorong tubuh LE. Kemudian SA menyerang LI dengan mendorong tubuh LI. Setelah itu SA menyerang LE dengan menjatuhkan tubuh LE dan LI ke karpet. Ketika SA menendang kaki LE dia juga menirukan suara pemain dalam game. Guru sudah memperingatkan untuk menghentikan aksi SA, namun SA tetap menyerang LI. SA menyerang kedua temannya seolah-olah dia seperti memainkan game yang biasa dimainkan.

\section{Akibat Perilaku Agresif Anak}

Anak berperilaku agresif tentunya dapat menimbulkan akibat-akibat yang tentunya merugikan lingkungan di sekitarnya. Akibat tersebut mengenai sasaran yang mana sasarannya terdiri dari teman maupun keluarganya sendiri. Adapun akibat perilaku agresif LI diantaranya yaitu sasarannya menjadi terganggu, sasaran dijauhi teman yang lain, sasaran membalas perbuatan LI dan LI dijauhi oleh temannya. Sedangkan akibat perilaku agresif DA diantaranya yaitu sasarannya menjadi terganggu dan sasarannya mengeluh sakit. Adapun akibat perilaku agresif SA diantaranya yaitu sasarannya menjadi terganggu, sasaran mengeluh sakit, sasaran membalas SA.

\section{Jenis Game}

Anak-anak yang ditemukan

sering berperilaku agresif diketahui memiliki kebiasaan bermain game ketika sedang di rumah. Jenis game yang dimainkan oleh LI adalah game Flying Dragon, Drive Army Football, Demont Hunt: The Legend Wars, Talking Tom Cat, Football League Dunia dan Dumb Ways to Die. Game Flying Dragon, Demont Hunt: The Legend War merupakan jenis game pertarungan.

DA bermain game Kungfu, Super Hero, Choki-choki AR Boboiboy dan Hot Wheels: Race Off. Game Kungfu, Super Hero, Choki-choki AR Boboiboy merupakan jenis game pertarungan. Sedangkan SA bermain game Hot Wheels: Rice Off, Chokichoki AR Boboiboy, Bus Simulator Indonesia, GTA, Bima $\mathrm{X}$, dan IDBS Simulator Bus Lintas Sumatera. Game Choki-choki AR Boboiboy, GTA, dan Bima $\mathrm{X}$ adalah jenis game pertarungan.

Jenis game pertarungan lebih sering dimainkan oleh LI dan, DA dibandingkan dengan game yang lain. Sedangkan untuk SI lebih sering memainkan game balapan daripada game pertarungan. Jenis game pertarungan yang menjadi favorit dan sering dimainkan anak memiliki unsur kekerasan di dalamnya. Bentuk kekerasan seperti adegan berkelahi antara pemain dan musuh/lawannya. Tindakan kekerasan yang disajikan berupa fisik yang berupa memukul dan menendang. selain itu diketahui pula jenis perangkat yang dimainkan oleh ketiga anak tersebut menggunakan tablet/handphone.

\section{Peran Orangtua}

Sikap orangtua ketika anak bermain game belum sepenuhnya terlibat. Ibu LI mendampingi anak bermain game tetapi hanya sekedar melihat saja. Orangtua DA mendampingi anak saat bermain game ketika sedang tidak ada kesibukan. Bentuk pendampingan tersebut seperti mengingatkan anak untuk tidak mendekatkan layar HP ke mata terlalu dekat dan bertanya-tanya mengenai game yang sedang dimainkan. Sedangkan sikap orangtua SA belum terlihat. Peran orangtua dalam memilihkan game semuanya hampir berperan. Tetapi begitu melihat respon anak yang tidak mau dipilihkan, orangtua membiarkan anak tersebut bermain game 
bebas sesuai keinginan anak.

Sebelumnya, orangtua sudah membuat peraturan bermain game. Hal ini ditujukan agar anak tidak menjadi kecanduan. Peraturan tersebut berisikan mengenai batasan waktu anak dalam bermain game dengan batas maksimal waktu yang berbeda-beda. Namun orangtua belum cukup tegas untuk menerapkan aturan tersebut pada anak.

\section{Pembahasan}

Secara lebih singkat, gambaran dinamika perilaku ketiga subjek menurut Teori ABC dituangkan ke dalam Tabel 2. sebagai berikut.

Tabel 2. Dinamika Perilaku Masing-Masing Subjek Dinamika Perilaku LI

\begin{tabular}{c|c|c}
\hline Antecendent & Behavior & Consequence \\
\hline $\begin{array}{c}\text { Bermain } \\
\text { fighting game }\end{array}$ & $\begin{array}{c}\text { Menendang } \\
\text { (CL.01) }\end{array}$ & $\begin{array}{c}\text { Sasaran merasa } \\
\text { terganggu }\end{array}$ \\
\hline $\begin{array}{c}\text { Bermain } \\
\text { fighting game }\end{array}$ & $\begin{array}{c}\text { Memukul } \\
\text { (CL.03) }\end{array}$ & $\begin{array}{c}\text { Sasaran } \\
\text { membalas } \\
\text { perbuatan LI }\end{array}$ \\
\hline Perbedaan & Mengejek & LI dijauhi \\
pendapat & (CL.04) & teman \\
dengan teman & & \\
\hline
\end{tabular}

\begin{tabular}{|c|c|c|}
\hline \multicolumn{3}{|c|}{ Dinamika Perilaku DA } \\
\hline $\begin{array}{c}\text { Bermain } \\
\text { fighting game }\end{array}$ & $\begin{array}{c}\text { Memukul } \\
\text { (CL.13) }\end{array}$ & $\begin{array}{c}\text { Sasaran merasa } \\
\text { terganggu }\end{array}$ \\
\hline $\begin{array}{c}\text { DA memaksa } \\
\text { keinginannya } \\
\text { harus } \\
\text { dipenuhi }\end{array}$ & $\begin{array}{l}\text { Menarik baju } \\
\quad(\text { CL.17) }\end{array}$ & $\begin{array}{c}\text { Sasaran merasa } \\
\text { terganggu }\end{array}$ \\
\hline $\begin{array}{c}\text { Bermain } \\
\text { fighting game }\end{array}$ & $\begin{array}{l}\text { Menendang } \\
\text { (CL.02) }\end{array}$ & $\begin{array}{c}\text { Sasaran merasa } \\
\text { terganggu }\end{array}$ \\
\hline $\begin{array}{c}\text { DA memaksa } \\
\text { keinginannya } \\
\text { harus } \\
\text { dipenuhi }\end{array}$ & $\begin{array}{c}\text { Mendorong } \\
\text { (CL.17) }\end{array}$ & $\begin{array}{c}\text { Sasaran merasa } \\
\text { terganggu }\end{array}$ \\
\hline $\begin{array}{c}\text { Bermain } \\
\text { adegan } \\
\text { fighting game }\end{array}$ & $\begin{array}{l}\text { Menindih } \\
\text { (CL.02) }\end{array}$ & $\begin{array}{c}\text { Sasaran } \\
\text { meraung } \\
\text { kesakitan }\end{array}$ \\
\hline $\begin{array}{c}\text { Menginginkan } \\
\text { balok yang } \\
\text { sama dengan } \\
\text { sasaran }\end{array}$ & $\begin{array}{l}\text { Merebut } \\
\text { mainan } \\
(\mathrm{CL} .06)\end{array}$ & $\begin{array}{c}\text { Sasaran merasa } \\
\text { terganggu }\end{array}$ \\
\hline $\begin{array}{c}\text { Gambaran NE } \\
\text { tidak bagus }\end{array}$ & $\begin{array}{l}\text { Mengejek } \\
\text { (CL.12) }\end{array}$ & $\begin{array}{l}\text { Sasaran merasa } \\
\text { terganggu }\end{array}$ \\
\hline $\begin{array}{c}\text { DA memaksa } \\
\text { keinginannya } \\
\text { harus } \\
\text { dipenuhi }\end{array}$ & $\begin{array}{l}\text { Mengancam } \\
\text { (CL.12) }\end{array}$ & $\begin{array}{l}\text { Sasaran merasa } \\
\text { terganggu }\end{array}$ \\
\hline \multicolumn{3}{|c|}{ Dinamika Perilaku SA } \\
\hline $\begin{array}{c}\text { Bermain } \\
\text { fighting game }\end{array}$ & $\begin{array}{l}\text { Memukul } \\
\text { (CL.08) }\end{array}$ & $\begin{array}{c}\text { Sasaran } \\
\text { membalas }\end{array}$ \\
\hline
\end{tabular}

\begin{tabular}{c|c|c} 
& & perbuatan SA \\
\hline Bermain & Menendang & Sasaran \\
fighting game & (CL.15) & membalas \\
& & perbuatan SA \\
\hline
\end{tabular}

Berdasarkan penelitian yang telah dilakukan, anak lebih sering menggunakan bentuk perilaku fisik. Perilaku agresif fisik yang sering dilakukan anak adalah memukul, menarik baju dan tangan, menendang, mendorong, menindih dan merebut mainan. Perilaku-perilaku tersebut ditemukan pada anak yang berjenis kelamin laki-laki. Hal ini sesuai dengan yang telah dinyatakan oleh Izzaty (2005: 16) bahwa perilaku agresif seringnya dilakukan oleh anak laki-laki karena terdapat pandangan jika anak laki-laki tidak boleh cengeng dan menangis.

Anak lebih sering menggunakan bentuk fisik dikarenakan terdapat anteseden yang mana diketahui anak tersebut telah memiliki kebiasaan bermain fighting game yang di dalamnya terdapat unsur kekerasan. Dalam permainan tersebut terdapat adegan berkelahi seperti memukul, menendang utamanya menyerang lawan terlebih dahulu. Jenis game ini seharusnya dimainkan oleh remaja, tetapi anak-anak sudah mulai menggemarinya. Hal ini seperti yang dikemukakan oleh Krahe (2005: 192) bahwa anak-anak lebih menyukai kekerasan yang terdapat di game daripada orang dewasa karena anak-anak sedang menunjukkan masa peka yang menunjukkan individu paling rentan terhadap pengaruh media seperti game.

Diketahui anak menirukan adegan pemain dalam game ketika hendak menyerang temannya. Anak tersebut berperilaku demikian seolah-olah dia adalah pemain yang ada di dalam game dan membuat anak kehilangan pengendalian diri. Perilaku anak yang demikian terjadi karena pada masa usia dini merupakan masa meniru yang dikemukakan oleh Bandura dengan menyebutnya learning by modelling. Dalam teori tersebut terdapat 4 tahapan belajar memodelkan peran seperti atensi, retensi, produksi dan motivasi. Pada proses atensi anak akan menaruh perhatian yang besar terhadap game yang membuat dia 
menantang dan mengasyikan. Kegiatan ini dapat berlangsung berulangkali sampai anak merasa memodelkannya. Proses selanjutnya retensi. Anak mulai mentransfer adegan yang ada dalam game ke memorinya. Selanjutnya produksi, anak mencoba memodelkan adegan tersebut seperti memukulnya, menendangnya, dll. Terakhir proses motivasi, hal ini dipengaruhi faktor dari luar diri anak yang memungkinkan anak menampilkan model tersebut. (Suyanto, 2005: 114-116).

Ketika perilaku sudah terbentuk karena dipengaruhi anteseden maka akan muncul konsekuensi yang harus diterima oleh anak dan tentu juga dapat merugikan lingkungan sekitarnya. Adapun konsekuensi tersebut terdiri dari sasaran dijauhi teman-teman yang lain, sasaran menjadi terganggu, sasaran membalas perlakuan anak yang berperilaku agresif, pelaku agresif dijauhi teman yang lain, sasaran mengelah kesakitan dan sasaran membalas perlakuan pelaku agresif.

Konsekuensi disini berfungsi sebagai mengulangi perilaku agresif yang dilakukan anak seperti yang telah dikemukakan oleh Holland dan Skinner (Priyoto, 2014: 126)

Penyebab perilaku agresif anak selain bermain game juga dipengaruhi faktor peran orangtua. Peran orangtua disini bertindak sebagai other contributing. Ketika anak bermain game, didapati bahwa hanya satu orangtua melakukan pendampingan jika tidak sedang sibuk. Adapun pendampingan tersebut seperti mengingatkan anak untuk tidak mendekatkan handphone ke mata terlalu dekat dan bertanya-tanya mengenai game yang sedang dimainkan. Orangtua juga ikut memilihkan game yang boleh dimainkan sesuai usia anak. Jika anak tidak mau dipilihkan maka anak dibiarkan bermain game sesuai dengan yang diinginkan seperti ada adegan pertarungan, maka orangtua ikut mengontrol dan menjelaskan bahwa tindakan seperti itu tidak boleh untuk dilakukan. Sedangkan kedua orangtua yang lain belum memaksimalkan waktunya untuk melakukan pendampingan pada anak saat bermain game.
Bentuk pendampingan tersebut sebagai wujud kontrol orangtua sebagai peletak dasar kepribadian anak yang sesuai dengan teori mikrosistem oleh Bronfenbrenner. Orangtua perlu mengetahui informasi yang didapat oleh anak-anak dan melakukan kontrol penggunaan handphone saat digunakan untuk bermain game. Saat anak di luar rumah, orangtua tidak dapat mengendalikan semua yang dilihat, dimainkan dan dimakan oleh anak. Oleh karena itu orangtua harus benar-benar memanfaatkan waktu saat anak berada di rumah untuk mengawasi anak bermain game dan memberikan kesempatan untuk melakukan aktivitas selain bermain game (Myers\&David, 2012: 105-106).

Diketahui bahwa terdapat aturan saat anak bermain game yang berisikan mengenai batasan waktu anak dalam bermain game dengan batas maksimal waktu yang berbeda-beda dan larangan mendekatkan handphone ke mata. Hal yang sama juga diungkapkan oleh Edy (2015: 12) orangtua perlu memberikan batasan waktu penggunaan handphone utamanya untuk bermain game. Selain itu anak juga diberi penjelasan mengenai aturan tersebut dibuat. Dalam penerapannya anak masih melanggar peraturan tersebut. Hal ini terjadi ketika anak tidak didampingi orangtua saat bermain game dan anak merasa terlalu asyik bermain game sehingga lupa waktu.

Selain peran orangtua, peran teman sebaya juga berpengaruh dalam pembentukan perilaku anak. Diketahui anak sering bermain dengan teman-teman yang sesama berperilaku agresif. Adapun skema dinamika perilaku agresif anak yang bermain game di TK ABA. 
Gambar 1. Wonocatur Banguntapan Bantul.

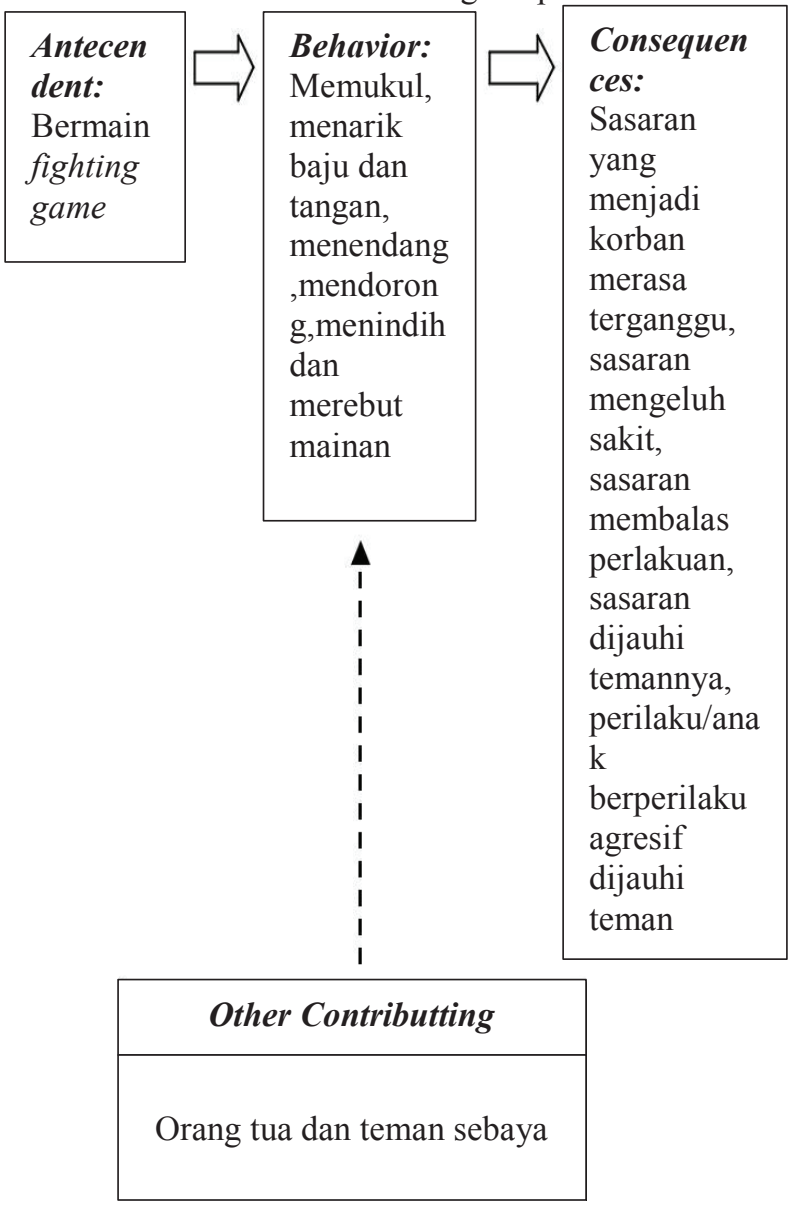

\section{KESIMPULAN \\ Kesimpulan}

Berdasarkan penelitian yang telah dilakukan mengenai dinamika perilaku agresif anak yang bermain game pada anak Kelompok B4 di TK ABA Wonocatur Banguntapan Bantul dapat disimpulkan sebagai berikut.

1. Anak lebih sering menggunakan bentuk perilaku fisik. Perilaku agresif fisik yang sering dilakukan anak adalah memukul, menarik baju dan tangan, menendang, mendorong, menindih, merebut mainan, dan menyoret pipi.

2. Anak lebih sering berperilaku agresif berbentuk fisik dikarenakan terdapat anteseden yang mana diketahui anak tersebut memiliki kebiasaan bermain fighting game yang di dalamnya terdapat unsur kekerasan. Dalam permainan tersebut terdapat adegan berkelahi seperti memukul dan menendang lawan terlebih dahulu. Diketahui anak menirukan adegan pemain dalam game ketika hendak menyerang temannya. Perilaku anak yang demikian terjadi karena pada masa usia dini merupakan masa meniru yang dikemukakan oleh Bandura dengan menyebutnya learning by modelling.

3. Ketika perilaku sudah terbentuk karena dipengaruhi anteseden, maka akan muncul konsekuensi yang harus diterima oleh anak dan tentu juga dapat merugikan lingkungan sekitarnya. Adapun konsekuensi tersebut terdiri dari sasaran dijauhi teman-teman yang lain, sasaran menjadi terganggu, sasaran membalas perlakuan anak yang berperilaku agresif, pelaku agresif dijauhi teman yang lain, sasaran mengelah kesakitan, dan sasaran membalas perlakuan pelaku agresif.

4. Penyebab perilaku agresif anak selain bermain game juga dipengaruhi faktor peran orangtua. Peran orangtua di sini bertindak sebagai other contributing. Peran orangtua belum terlihat maksimal ketika mendampingi anak bermain game. Orangtua belum tegas menerapkan aturan dan hukuman bagi anak.

\section{Saran}

Orangtua perlu berkomunikasi dengan anak mengenai perilaku apa yang diperbolehkan dan tidak diperbolehkan. Orangtua harus lebih dapat mengontrol dan mendampingi setiap anak bermain game. Orangtua perlu mengetahui isi game dan tidak membiarkan anak bermain game yang terdapat unsur kekerasan. Orangtua juga perlu mempertegas kembali aturan bermain game dan jika anak melanggar harus ada hukuman bagi anak agar anak merasa memiliki tanggungjawab dan disiplin.

Sedangkan bagi guru dapat memberikan pesan-pesan ketika di sekolah terkait adegan kekerasan di dalam game yang tidak boleh ditiru dan menyarankan untuk tidak bermain game. Selain itu, guru juga melakukan kontrol apabila sewaktuwaktu anak berperilaku agresif.

Bagi peneliti selanjutnya, penelitian ini dapat dimanfaatkan untuk penelitian lebih lanjut dan masalah lain yang ada kaitannya dengan sebab-sebab terjadinya perilaku negatif pada anak usia dini. Bagi peneliti yang akan melakukan penelitian serupa, dapat menggunakan jenis dan 
metode penelitian yang lain. Selain itu, peneliti yang akan melakukan penelitian serupa dapat menggunakan wilayah yang berbeda. Hal ini dikarenakan wilayah generalisasi penelitian ini terbatas sehingga hasil penelitian juga hanya berlaku untuk suatu ruang lingkup saja.

\section{DAFTAR PUSTAKA}

Arriani, F. (2014). Perilaku agresif anak usia dini. Diambil pada tanggal 17 Februari 2017 dari http://jurnalma hasiswa .unesa.ac.id/index.php/jurnal-bkunesa/article/view/6714/9187.

Craig et.al. (2001).Effects of violent video games on aggressive behavior, aggressive cognition, aggressive affect, physiological arousal, and prosocial behavior: a meta-analytic review of the scientific literature. Diambil pada tanggal 27 Maret 2017 dari https://public.psych.iastate.edu/caa/ abstra cts/2000-2004/01AB.pdf.

Edy, A. (2015). Ayah edy menjawab problematika orangtua $A B G$ dan remaja. Jakarta: Noura Book Publising.

Erlianti \& Dwiyanti. (2014). Analisis perilaku aman tenaga kerja menggunakan model perilaku $A B C$ (antecedent behavior consequence). Diambil pada tanggal 9 Oktober 2017 dari http://journal.unair.ac.id.pdf.

Fajri, I.N. (2014). Kajian umum teori B.F. Skinner. Diambil pada tanggal 10 Oktober 2017 dari www.academia.edu/8494475/B F $\underline{\text { Skinner }}$

Henry, S. (2010). Cerdas dengan game: panduan praktis bagi orangtua dalam mendampingi anak bermain game. Jakarta: PT
Gramedia Pustaka Utama.

Izzaty, R.E (2005). Mengenal permasalahan perkembangan anak usia TK. Jakarta: Departemen Pendidikan Nasional, Direktorat Jenderal Pendidikan Tinggi, Direktorat Pembinaan Pendidikan Tenaga Kependidikan dan Ketenagaan Perguruan Tinggi.

Krahe, B. (2005). Perilaku agresi. (Alih bahasa: Helly Prajitno). Yogyakarta: Pustaka Pelajar.

Kholid, A. (2012). Promosi kesehatan dengan pendekatan teori perilaku, media dan aplikasinya. Jakarta: PT Raja Grafindo Persada.

Mashar, R. (2011). Emosi anak usia dini dan strategi pengembangannya. Jakarta: Prenadamedia Group.

Musbikin, I. (2009). Mengapa ya anakku kok suka berbohong? Yogyakarta: Diva Press.

Myers \& David. (2012). Psikologi sosial. (Alih bahasa: Aliya Tusyani). Jakarta: Salemba Humanika.

Nors, I. (2011) Perilaku agresif: penyebab dan penanganannya. Diambil pada tanggal 17 Januari 2017 dari http ://m.kompasiana.com/icha nors/peri laku-agresif-penyebab-danpenangananny a5509803a8133117249b1e23e.

Priyoto. (2014). Teori sikap dan perilaku dalam kesehatan dilengkapi dengan contoh kuesioner. Yogyakarta: Nuha Medika.

Purwanto, E. (2012). Modifikasi perilaku: alternative penanganan anak berkebutuhan khusus. Yogyakarta: Pustaka Pelajar.

Rahman, A.A (2013). Psikologi sosial: integrasi pengetahuan wahyu dan 
pengetahuan empirik. Jakarta: PT Raja Grafindo Persada.

Saefi, M. (2010). Pengertian perilaku agresif. Diambil pada tanggal 17 Januari 2017 dari http://belajarpsikologi.com/pengert ian-perilaku-agresif/.

Sokolova, I.V. et.al. (2014). Kepribadian anak: sehatkah kepribadian anak anda?. (Alih bahasa: Abdul Qodir Shaleh). Yogyakarta: Katahati.

Singgih D. G. (2006).

Dasar dan teori perkembangan anak. Jakarta: Gunung Mulia.

Suyanto. (2005). Konsep dasar pendidikan anak usia dini. Jakarta:

Departemen Pendidikan Nasional, Direktorat Jenderal Pendidikan Tinggi, Direktorat Pembinaan Pendidikan Tenaga

Kependidikan dan Ketenagaan Perguruan Tinggi.

Vanri, K.F. \& Hasbiyalloh (2011). Games online dan katarsis virtual : studi kasus dengan analisis psikoanalisis freud pada kecenderungan permainan game interaktif point blank dan second life. Diambil pada tanggal 26 Januari 2017 dari http://ejournals.umn.ac.id/index.ph $\mathrm{p} / \mathrm{Ilko} \mathrm{m} /$ article/view/198.

Wiyani, N.A. (2014). Mengelola \& mengembangkan kecerdasan sosial \& emosi anak usia dini. Yogyakarta: Ar-Ruz Media. 